\title{
Inhibition mechanism of Listeria monocytogenes by a bioprotective bacteria Lactococcus piscium CNCM I-4031
}

\author{
Saraoui Taous ${ }^{1,2,4}$, Fall Papa-Abdoulaye ${ }^{1,2,4}$, Leroi Francoise ${ }^{1}$, Antignac Jean-Philippe ${ }^{3}$, \\ Chéreau Sylvain ${ }^{3}$, Pilet Marie-France ${ }^{2,4, *}$
}

${ }^{1}$ Laboratoire Ecosystèmes Microbiens et Molécules Marines pour les Biotechnologies (EM3B), Ifremer, Rue de l'lle d'Yeu, 44311 Nantes Cedex 03, France

${ }^{2}$ LUNAM Université, Oniris, UMR 1014 Secalim, Site de la Chantrerie, Nantes, F-44307, France

3 LUNAM Université, Oniris, USC INRA 1329 Laboratoire d'Etude des Résidus et Contaminants dans les Aliments (LABERCA), Nantes, F-44307, France

${ }^{4}$ INRA, Nantes, F-44307, France

* Corresponding author : Marie-France Pilet, Tel.: +33 240687811; fax: +33 240687762 ; email

address : marie-france.pilet@oniris-nantes.fr

\begin{abstract}
:
Listeria monocytogenes is a pathogenic Gram positive bacterium and the etiologic agent of listeriosis, a severe food-borne disease. Lactococcus piscium CNCM I-4031 has the capacity to prevent the growth of $L$. monocytogenes in contaminated peeled and cooked shrimp. To investigate the inhibititory mechanism, a chemically defined medium (MSMA) based on shrimp composition and reproducing the inhibition observed in shrimp was developed. In co-culture at $26^{\circ} \mathrm{C}$, L. monocytogenes was reduced by 3-4 log CFU g- 1 after $24 \mathrm{~h}$. We have demonstrated that the inhibition was not due to secretion of extracellular antimicrobial compounds as bacteriocins, organic acids and hydrogen peroxide. Global metabolomic fingerprints of these strains in pure culture were assessed by liquid chromatography coupled with high resolution mass spectrometry. Consumption of glucose, amino-acids, vitamins, nitrogen bases, iron and magnesium was measured and competition for some molecules could be hypothesized. However, after $24 \mathrm{~h}$ of co-culture, when inhibition of L. monocytogenes occurred, supplementation of the medium with these compounds did not restore its growth. The inhibition was observed in co-culture but not in diffusion chamber when species were separated by a filter membrane. Taken together, these data indicate that the inhibition mechanism of $L$. monocytogenes by L. piscium is cell-to-cell contact-dependent.
\end{abstract}

\section{Highlights}

A chemically defined medium (MSMA) was developed to study bacterial interactions. Lactococcus piscium CNCM I-4031 inhibits the growth of $L$. monocytogenes as in shrimp. This interaction requires contact between both strains. - First report of contact dependant inhibition between a $L A B$ and $L$. monocytogenes.

Keywords : Listeria monocytogenes, Lactococcus piscium, nutrients competition, cellular contact, chemically defined medium, bacterial interaction 


\section{Introduction}

Listeria monocytogenes is an opportunistic pathogenic Gram positive bacterium and the etiologic agent of listeriosis, a severe food-borne disease (Vazquez-Boland et al., 2001) with high hospitalization cases ( 300 cases/year from 2006 to 2011 in France) and high fatality rates (20 to $30 \%)$. The populations at greatest risk are newborn infants, pregnant women, elderly persons, and persons with a weak immune system (Lecuit and Leclercq, 2012). L. monocytogenes is able to grow in most of the conditions found in the food chain, such as high salt concentrations, presence of $\mathrm{CO}_{2}$, and low temperatures. The resistance of this bacterium to these environmental factors makes this organism difficult to control in refrigerated food product (Gandhi and Chikindas, 2007). Many studies have been published concerning the inhibition of L. monocytogenes using various preservation technologies. Biopreservation technique which consists in using natural, selected protective microorganisms, was demonstrated as an efficient strategy for the control of L. monocytogenes in a variety of ready-to-eat seafood or meat products (Ananou et al., 2005; Benkerroum et al., 2005; Pilet and Leroi, 2011). Lactic acid bacteria (LAB) are excellent candidates for preventing the growth of pathogenic bacteria in food products because they show bacteriostatic effect towards many bacterial species through various mechanisms, without causing unacceptable sensory changes in foodstuffs (Stile, 1996; Ghanbari et al., 2013). The growth inhibition of the target bacteria when LAB have reached their maximum level is usually described as Jameson effect (Jameson, 1962)). These inhibitions sometimes involve well known antagonist mechanisms such as production of antimicrobial compounds as bacteriocins, bacteriocin-like inhibitory substance (Richard et al., 2003; Schöbitz et al., 2003 ; Naghmouchi et al., 2006,2007 ; Rihakova et al., 2009), or reuterin (El-Ziney et al., 1999), organic acid (Alomar et al., 2008a) or hydrogen peroxide (Delbes-Paus et al., 2010). However, in some cases, the production of inhibiting metabolites is not evidenced and other hypothesis must be tested. As an example, Nilsson et al. (2005) have demonstrated the involvement of glucose competition in the inhibition of L. monocytogenes by a non-bacteriocin producing Carnobacterium piscicola. In a recent study, a protective strain, Lactococcus piscium CNCM I-4031, was isolated from salmon steak stored under modified atmosphere. This strain was able to improve sensory quality of seafood (Matamoros et al., 2009a,b) by preventing the growth of Brochothrix thermosphacta (Fall et al., 2010b). L. piscium CNCM I-4031 has also shown its ability to limit the growth of L. monocytogenes during the storage of cooked shrimp (Fall et al., 2010a). The aim of the present study was to gain insight the mechanism involved in the 
inhibition of L. monocytogenes by L. piscium CNCMI-4031 as it is one of the required knowledge on protective flora to ensure their possible acceptability and use for food preservation. For this purpose, a chemical defined medium close to shrimp composition has been first set up to reproduce the inhibition of L. monocytogenes by L. piscium observed in shrimp matrices. Then different tests to investigate the mechanisms have been developed.

\section{Materials and methods}

\subsection{Bacterial strains, culture media and conditions}

L. piscium CNCM-I 4031 was isolated from fresh salmon steak packed under modified atmosphere (Matamoros et al., 2009a). The target strain L. monocytogenes RF191 was isolated from tropical cooked peeled shrimp by PFI Nouvelles Vagues (Boulogne-sur-mer, France) and used before as target strain in challenge-tests (Fall et al., 2010a). The two strains were stored at $-80^{\circ} \mathrm{C}$ in their culture media with $20 \%$ glycerol (Panreac, Barcelona, Spain). For all experiments, L. piscium and L. monocytogenes were subcultured in Elliker broth and Brain Heart Infusion (BHI) supplemented with 2\% NaCl (Biokar Diagnostic, Beauvais, France) respectively for $24 \mathrm{~h}$ at $26^{\circ} \mathrm{C}$. The cultures were diluted in their culture media, if necessary, to obtain appropriate initial cell concentrations. L. piscium was enumerated on spread Elliker agar plates after incubation at $8^{\circ} \mathrm{C}$ for 5 days under anaerobiosis and $L$. monocytogenes on spread Palcam agar plates (Biokar) incubated at $37^{\circ} \mathrm{C}$ for $24 \mathrm{~h}$.

\subsection{Chemically defined medium set up}

To improve the bacteria growth, six different media were prepared by supplementing the MSM with the different compounds listed in Table 1 and recommended by Premaratne et al. (1991), Jensen and Hammer (1993), Lauret et al. (1996) and Fall et al. (2012).

The components were prepared as concentrated solution of mix or single solution to avoid medium precipitation. All the amino acids (Sigma Aldrich, Saint-Louis, MO, United-States) were mixed except tyrosine, glutamine and cysteine that were used as single solutions. Vitamins (Sigma Aldrich) were separated in two mix containing riboflavine, thiamine, niacine, vitamin B12 and vitamin D for mix 1 or folic acid, aminobenzoic acid, and piridoxal (vitamin B6) for mix 2. Adenine, guanine, uracil (Sigma Aldrich) and glucose (Merck, Darmstadt, Germany) were prepared as single solutions. All these components were dissolved in distilled water and filter sterilized using Acrodisc 0.45- $\mu \mathrm{m}$-pore-size membrane (Sartorius Stedim Biotech, Goettingen, Germany) and can be stored at $-20^{\circ} \mathrm{C}$ (mix of amino acids and 
vitamins) or $4^{\circ} \mathrm{C}$ up to 15 days. Salts solution containing ammonium citrate, magnesium sulfate or sodium chloride (Merck) were prepared separately in distilled water, sterilized for $15 \mathrm{~min}$ at $121^{\circ} \mathrm{C}$ and stored at $4^{\circ} \mathrm{C}$ up to 15 days. The final media were prepared by mixing the components in the following order : ammonium citrate, magnesium sulfate, sodium chloride, mix of amino acids, glucose, adenine, guanine, uracil, tyrosine, glutamine, cysteine, phosphate buffer [final molarity $\mathrm{Na}_{2} \mathrm{HPO}_{4} 7 \mathrm{H}_{2} \mathrm{O}(0.11 \mathrm{M})$ and $\mathrm{KH}_{2} \mathrm{PO}_{4}(0.05 \mathrm{M})$ ] and finally mix 1 and mix 2 of vitamins. The final $\mathrm{pH}$ was 7.0.

Fresh MSMA to -F media were then inoculated at $10^{4} \mathrm{CFU} \mathrm{ml}{ }^{-1}$ with overnight subcultured strains and growth at $26^{\circ} \mathrm{C}$ was monitored by Petri dish enumeration technique.

\subsection{Shrimp juice}

The shrimp juice was prepared by crushing thawed raw peeled shrimp in a Warring Blender (New Hartford, CT, USA) with distilled water. The mixture was then boiled for 2 min and filtered through a filter (no.127, Durieux, Paris, France). $\mathrm{NaCl} 20 \mathrm{~g} \mathrm{l}^{-1}$ was added to the clear broth obtained before autoclaving at $100^{\circ} \mathrm{C}$ for $30 \mathrm{~min}$ (Fall et al., 2010b) and growth of strains was performed as in MSM.

\subsection{Antimicrobial assay \\ - Agar spot assay}

The presence of antimicrobial compounds in L. piscium culture or co-culture with $L$. monocytogenes was evaluated using solid $\mathrm{BHI}(2 \% \mathrm{NaCl})$ agar spot assay (Matamoros et al., 2009a). The supernatant of L. piscium was obtained after centrifugation of $10 \mathrm{ml}$ of a $24 \mathrm{~h}$ culture or co-culture $\left(11600 \mathrm{~g}\right.$ for $10 \mathrm{~min}$ at $\left.4^{\circ} \mathrm{C}\right)$. The supernatant was then filter sterilized $(0.45-\mu \mathrm{m})$. One milliliter of a suspension containing $10^{6} \mathrm{CFU} \mathrm{ml}^{-1}$ of L. monocytogenes was poured in $15 \mathrm{ml} \mathrm{BHI}$ agar plates $(2 \% \mathrm{NaCl}, 1 \%$ agar) and kept at room temperature for $15-20$ min. Ten microliters of filtered supernatant were then dropped (as a spot) onto the solidified BHI agar and the plates were incubated 24 to $72 \mathrm{~h}$ at $26^{\circ} \mathrm{C}$ to detect inhibition zones around the spots.

\section{- Inhibition test after protein purification}

The precipitation of potential antimicrobial peptides was performed by treatment of supernatant using ammonium sulfate precipitation. Ammonium sulfate was added to the filtered supernatant at saturation of $40 \%$ and $80 \%$ (http://www.encorbio.com/protocols/AM$\underline{\text { SO4.htm }})$ for $1 \mathrm{~h}$ under stirring. After centrifugation $\left(10000 \mathrm{~g}, 15 \mathrm{~min}, 4^{\circ} \mathrm{C}\right)$, the supernatant 
was removed and the precipitate was resuspended and concentrated 10 fold in distilled water. The $\mathrm{pH}$ was adjusted to 6.9 and the suspension was filter sterilized and tested using solid BHI $(2 \% \mathrm{NaCl})$ spot agar assay as described above.

\section{- inhibition test after cells treatments}

To remove the putative proteins linked to the L. piscium membrane, cultures in MSMA, $\left(24 \mathrm{~h}\right.$ at $26^{\circ} \mathrm{C}$ ) were acidified for $2 \mathrm{~h}$ at $\mathrm{pH} 2$ with $\mathrm{HCl} 10 \mathrm{M}$. The $\mathrm{pH}$ was then adjusted to its initial value with $\mathrm{NaOH}(10 \mathrm{M})$ and the supernatant was tested after ammonium sulfate precipitation by agar spot assay.

The internal content of L. piscium cell was tested as follows: cells from L. piscium ( $24 \mathrm{~h}$ at $26^{\circ} \mathrm{C}$ in MSMA medium) were pelleted by centrifugation (11600 g, $10 \mathrm{~min}$ ) and disrupted using $0.2 \mathrm{~g}$ of glass beads (150 to $200 \mu \mathrm{m}$ diameter) and shaking twice for $2 \mathrm{~min}$ in a bead beater MM200 (30 Hz) (Fisher Bioblock Scientific, Illkirch-Graffenstaden, France). Cell fragments were then tested against L. monocytogenes using agar spot assay.

\subsection{Inhibition test in chemically defined medium}

\subsubsection{Sequential culture}

Bioprotective strain L. piscium was inoculated in fresh MSMA medium at 1\% (inoculation level: $10^{6} \mathrm{CFU} \mathrm{ml}{ }^{-1}$ ) and incubated at $26^{\circ} \mathrm{C}$. After $24 \mathrm{~h}$ incubation, the culture was centrifuged at $11600 \mathrm{~g}$ for $10 \mathrm{~min}$ and the supernatant was filter sterilized on $0.45 \mu \mathrm{m}$ filter membrane (Sartorius Stedim Biotech) to eliminate L. piscium cells. The resultant sterile pre-fermented medium was then inoculated with L. monocytogenes at $10^{3} \mathrm{CFU} \mathrm{ml}^{-1}$ and growth was monitored at $26^{\circ} \mathrm{C}$ by classical enumeration. A culture of L. monocytogenes in non prefermented MSMA was performed as control.

\subsubsection{Mixed culture (co-culture with cellular contact)}

L. piscium and L. monocytogenes were co-inoculated respectively at $10^{6} \mathrm{CFU} \mathrm{ml}^{-1}$ and $10^{3} \mathrm{CFU} \mathrm{ml}{ }^{-1}$ in MSMA medium. The culture was incubated at $26^{\circ} \mathrm{C}$ for $48 \mathrm{~h}$ and growth of the two strains was monitored as described in 2.1. Controls consisted in monoculture of each strain in MSMA at $26^{\circ} \mathrm{C}$.

\subsubsection{Diffusion chamber culture (co-culture without cellular contact)}

A double chambers system separated with a filter size of $0.22 \mu \mathrm{m}$ (Sartorius Stedim Biotech) was built by a local glassworker. The system was sterilized by autoclaving at $121{ }^{\circ} \mathrm{C}$, 
$15 \mathrm{~min}$, before assembling aseptically. Each chamber was filled with $150 \mathrm{ml}$ of MSMA and $L$. piscium was inoculated at $10^{6} \mathrm{CFU} \mathrm{ml}^{-1}$ in the first chamber whereas L. monocytogenes was inoculated in the second chamber at $10^{3} \mathrm{CFU} \mathrm{ml}^{-1}$. Monoculture of each strain was performed as control (strain in the first compartment and sterile MSMA in the second).

\subsection{Bacterial interaction mechanism}

\subsubsection{Metabolomic profile}

Metabolomic profiles were generated from $L$. piscium and L. monocytogenes cultures in MSMA after $48 \mathrm{~h}$ of incubation at $26^{\circ} \mathrm{C}$. Non inoculated MSMA was used as control. Fifteen milliliters of cultures were centrifuged at $8500 \mathrm{~g}$ for $10 \mathrm{~min}$ and the supernatant was filter sterilized with $0.22 \mu \mathrm{m}$ membrane filters (Sartorius Stedim Biotech) and stored at $-80^{\circ} \mathrm{C}$ before analysis. Each condition was repeated six times. Metabolomic fingerprints were acquired at LABERCA (Oniris, France) by liquid chromatography coupled to high resolution mass spectrometry (LC-HRMS) operating in the positive electrospray ionization mode (ESI+) and full scan acquisition mode (m/z 50 to 800) at a 30,000 resolution fwhm (Thermo Scientific LTQ® - Orbitrap instrument).

\subsubsection{Amino acid analysis}

The amino acids consumption of L. piscium and L. monocytogenes in MSMA medium was assessed. The analysis was performed in triplicates on supernatant after $48 \mathrm{~h}$ of culture at $26^{\circ} \mathrm{C}$ by High Performance Liquid Chromatography (HPLC, Kontron, Eching am Ammersee, Germany) according to the WATERSAccQ.Tag method. Briefly, 6-aminoquinolyl-Nhydroxysuccinimidyl carbamate (AQC) reacted with amino acids to form a fluorescent complex detected at $395 \mathrm{~nm}$ (spectrofluorimetry detector, Shimadzu RF-10XL). The separation was performed on C18 column with acetonitrile gradient from $8 \%$ to $30 \%$ during $23 \mathrm{~min}$ at $44.2^{\circ} \mathrm{C}$ at a flow of $1 \mathrm{ml} \mathrm{min}^{-1}$. Results were analyzed by Drylab software (MolnarInstitute, Berlin, Germany).

In this experimentation, a $\alpha$-aminobutyric acid $2.5 \mathrm{mM}$ was used as a internal standard.

\subsubsection{Glucose, lactic acid and pH analysis}

All the following analysis were performed in co-culture condition (mixed culture) and on control culture of each strain. L-lactic acid was measured on culture supernatant with the enzymatic kit 021 (Biosentec, Toulouse, France) according to supplier recommendation. Glucose was measured by the colorimetric method of Dubois et al (1956). The $\mathrm{pH}$ values 
were recorded with a Mettler pH-meter (Mettler Delta 320, HELSTEAD, UK) at each enumeration time.

A lactic acid supplementation was performed using a sodium lactate solution $\left(44.7 \mathrm{~g} \mathrm{l}^{-1}\right)$ diluted at a required concentration in MSMA.

\subsection{Effect of nutrients supplementation on L. monocytogenes co-cultured with L. pisicum}

Flasks containing $90 \mathrm{ml}$ of MSMA were freshly prepared and inoculated by L. piscium and L. monocytogenes at $10^{6}$ and $10^{3} \mathrm{CFU} \mathrm{ml}{ }^{-1}$ respectively before incubation at $26^{\circ} \mathrm{C}$. After $24 \mathrm{~h}$ of growth, when inhibition occurred, the following compounds amino acids mix, nitrogen bases, glucose, vitamins mix, iron citrate and magnesium sulfate were separately added in flasks of mixed cultures, to obtain initial concentration conditions (Table 1). One flask was supplemented with a mixture containing amino acids, nitrogen base and vitamins. The last flask used as control was completed with sterile water. All the samples were reincubated at $26^{\circ} \mathrm{C}$ for $24 \mathrm{~h}$ and bacterial growth was monitored by plate counts.

\section{Results and Discussion}

\subsection{Bacterial growth in MSMA media}

As shown in previous studies, the mechanism of inhibition involved in the interaction between L. piscium and L. monocytogenes was not due to bacteriocin production, $\mathrm{pH}$ decrease or lactic acid production (Matamoros et al., 2009b ; Fall et al. 2010a). The study of other interaction mechanisms like nutrient competition is usually performed through the development of chemically defined media (Nilsson et al., 2005; Nouaille et al., 2009) although it is known that the inhibitory effect is dependent of environmental parameters (Charlier et al., 2009). Using data from shrimp characterization (Fall et al., 2010b), composition different media developed for the growth of L. monocytogenes (Premaratne et al., 1991), Lactococcus lactis (Jensen and Hammer, 1993) or Lactobacillus sakei (Lauret et al., 1996), different media (basal MSM and MSMA to F, Table 1) were tested for their ability to allow the growth at $8^{\circ} \mathrm{C}$ of the protective and the target bacteria and to reproduce the inhibition observed in shrimp. Results from bacterial growth in monocultures (Table 2) showed a capacity of both strains to grow in all tested chemically defined media. The lowest growth rate was obtained in MSMD without vitamins and nitrogen acid whereas the best growth rates were observed in complete MSMF $\left(0.093 \mathrm{~h}^{-1}\right)$ or MSMA $\left(0.030 \mathrm{~h}^{-1}\right)$ for $L$. piscium and L. monocytogenes respectively. In comparison to MSMF, the growth of $L$. piscium in MSMA was slightly lower $\left(0.058 \mathrm{~h}^{-1}\right)$, which may be explained by the absence of 
taurine, a compound present in large quantities in shrimp (Fall et al., 2012; Heu et al., 2003). However, the MSMA medium allowing the both strains to grow with close growth rates was chosen to follow bacterial interaction. As the preliminary co-culture tests performed in this medium at $8^{\circ} \mathrm{C}$ were long, a temperature of $26^{\circ} \mathrm{C}$ close to L. piscium optimal growth temperature was chosen for the next experiments. In these conditions, the growth rates observed in MSMA medium increased 10 fold for both species, reaching $0.256 \mathrm{~h}^{-1}$ and 0.572 for L. piscium and L. monocytogenes respectively. Furthermore, in mixed culture performed in MSMA medium when L. piscium reached its maximum concentration, the growth of $L$. monocytogenes was totally stopped at $10^{6} \mathrm{CFU} \mathrm{ml}^{-1}$ after $20 \mathrm{~h}$ culture (Figure 1) as observed in shrimp during the first 4 days (Fall et al., 2010a). Following these results, the growth of $L$. piscium and L. monocytogenes in MSMA at $26^{\circ} \mathrm{C}$ was considered as an efficient model to study the interaction mechanism between these bacteria.

\subsection{Evaluation of culture supernatants for antimicrobial activity}

Recently, Matamoros et al. (2009b) have demonstrated that the inhibition of $L$. monocytogenes by L. piscium was not due to a bacteriocin-like compound in Elliker medium. However as the production of such antimicrobial molecules can be medium dependant, the production of secreted antimicrobial compounds was evaluated in MSMA using the agar spot test. No inhibition zones around the supernatant spot of a 24 or $48 \mathrm{~h}$ culture of L. piscium was observed.

To confirm these results, proteins contained in the supernatant were concentrated ten-fold by precipitation with ammonium sulfate to detect antimicrobial proteins that may be produced at low concentrations by the protective bacteria. Acidification of the medium was also used to release potential antimicrobial proteins or peptides that may adsorb on cell surface of $L$. piscium. In a last experiment, the inhibition potential of cell fragments obtained after glass bead disruption was tested. None of these experiments allowed obtaining the inhibition activity. The same results were obtained by repeating these experiments with supernatant or cell extracts of the mixed culture $\left(24 \mathrm{~h}\right.$ in MSMA, $\left.26^{\circ} \mathrm{C}\right)$ to search for a potential induction of bacteriocin production as shown in the case of Carnobacterium maltaromaticum (Himelbloom et al., 2001).

All these data suggest that excreted antimicrobial compounds are not clearly involved in the inhibition of L. monocytogenes by L. piscium unlike what is commonly described for other LAB in seafood (Ghanbari et al., 2013). 


\subsection{Organic acid production}

The L-lactic acid concentrations produced by each strain after $24 \mathrm{~h}$ of culture in MSMA were similar $\left(3.71 \pm 0.01 \mathrm{~g} \mathrm{l}^{-1}\right.$ for L. piscium and $3.73 \pm 0.09 \mathrm{~g} \mathrm{l}^{-1}$ for $L$. monocytogenes). In mixed culture the production reached $4.28 \pm 0.06 \mathrm{~g} \mathrm{l}^{-1}$. No acetic acid nor L-lactic acid was produced. A monoculture of L. monocytogenes was performed in buffered MSMA supplemented with $4.28 \mathrm{~g} \mathrm{l}^{-1}$ of lactic acid and compared to the monoculture in MSMA. The $\mathrm{pH}$ of the medium remained constant and no difference between both conditions was observed (data not shown). These observations indicated that the mechanism of inhibition is not due to production of lactic acid as demonstrated for other inhibition of pathogenic bacteria by LAB (Alomar et al., 2008a).

\subsection{Nutritional competition}

To determine the role of nutritional competition for some components of MSMA in the inhibition, the metabolomic fingerprints of L. piscium and L. monocytogenes cultured $48 \mathrm{~h}$ in MSMA were compared and sterile MSMA was added as control. Each test was performed in 6 independent cultures, allowing statistical analysis. Principal component analysis revealed a good discrimination of each strain on the basis of their global metabolic profiles (Figure 2), suggesting that the two strains have clearly different metabolisms on MSMA. The consumption of nutrients like nitrogen bases and vitamins was particularly investigated since they are difficult to measure using classical methods. Diagnostic signal of adenine, guanine and uracil represented in Figure 3A, B and C revealed that these bases were completely consumed by L. piscium and partially by L. monocytogenes. The rapid growth of L. piscium and its favourable initial ratio may lead to a quicker uptake and thus competition for those bases may be partially responsible for the inhibition. Riboflavin was the only vitamin totally consumed by both strains (Figure 3D) and could thus be involved in the competition. Amino acids concentrations were measured by HPLC, after $48 \mathrm{~h}$ of cultures at $26^{\circ} \mathrm{C}$ and are presented in Table 3. Cysteine, histidine and glycine were the major amino-acids consumed by L. piscium whereas L. monocytogenes also metabolized leucine, isoleucine and in few quantities the other amino-acids. These results are in agreement with those obtained in shrimp matrices where a weak amino-acids consumption was observed for L. piscium (Fall et al., 2012). The sums of the most amino acids uptake by L. piscium and L. monocytogenes were inferior to their initial concentration in MSMA. Competition for one of those nutrients is thus unlikely, except for cysteine which was almost totally consumed by the two strains, and in a lesser extends for histidine and glycine. 
To confirm these results, supplementations of mixed culture after $24 \mathrm{~h}$ at $26^{\circ} \mathrm{C}$ in MSMA with mix of all amino acids, mix of nitrogen bases, mix of vitamins, magnesium, iron and also a mix of all those compounds was performed. None of the nutrient supplementation tested allowed the re-growth of L. monocytogenes (Figure 4) which remained inhibited in all the conditions. These data clearly demonstrated that nutrients listed above were not involved in the interaction between the protective and the target strains. These results are in agreement with those obtained by Alomar et al. (2008b) who did not succeed to prove the amino acids implication in the inhibition of S. aureus by L. garvieae in microfiltered milk. Similarly, Nilsson et al. (2005) failed to suppress the inhibition of $L$. monocytogenes by $C$. maltaromaticum when supplementing the medium with amino acids or vitamins. In this last study, the authors have demonstrated the role of glucose consumption in the inhibition. When L. monocytogenes cultures either in diffusion chamber or in medium pre-fermented by $C$. maltaromaticum supplemented with glucose, it showed its ability to restart growing and suppress the inhibition effect. On the opposite, in our experiments, the glucose supplementation $\left(7 \mathrm{~g} \mathrm{l}^{-1}\right)$ during the co-culture did not restore L. monocytogenes growth. Moreover, in these conditions L. monocytogenes decreased from 7.1 to $5.3 \log \mathrm{CFU} \mathrm{m}{ }^{-1}$ in 7 $\mathrm{h}$, and no viable cells were detected after $10 \mathrm{~h}$ of culture (Figure 4). This result can probably be explained by the high acidification $(\mathrm{pH}=4.23)$ of the medium due to the growth and lactic acid production by L. piscium.

The initial glucose present in MSMA medium (7.00 $\left.\mathrm{g} \mathrm{l}^{-1}\right)$ was totally consumed in monoculture of L. monocytogenes, orL. piscium and in mixed culture after $24 \mathrm{~h}$ with values of $0.26 \pm 0.02,0.54 \pm 0.00 \mathrm{~g} \mathrm{l}^{-1}$ and $0.25 \pm 0.00 \mathrm{~g} \mathrm{l}^{-1}$ respectively. . In order to further investigate the hypothesis of competition for glucose, mixed cultures were performed in MSMA containing higher glucose concentration $\left(20.00 \mathrm{~g} \mathrm{l}^{-1}\right)$. In that case, the inhibition of $L$. monocytogenes was also observed whereas the final glucose concentration was $14.00 \mathrm{~g} \mathrm{l}^{-1}$ and no $\mathrm{pH}$ drop was observed, suggesting that glucose is not a limiting factor which could have explained the inhibition of L. monocytogenes.

All these results suggested that the inhibition of L. monocytogenes by L. piscium might involve other mechanisms than antimicrobial production or nutritional competition. It was confirmed by the ability of L. monocytogenes to grow in MSMA pre-fermented by L. piscium with the same growth rate $\left(0.572 \mathrm{~h}^{-1}\right)$ and same final concentration $\left(9 \log \mathrm{CFU} \mathrm{ml}{ }^{-1}\right)$ as in non pre-fermented MSMA (data not shown). The mechanism that is involved in this inhibition can thus not be compared to the one described by Nilsson et al. (2005) for L. monocytogenes and 
C. maltaromaticum for which the same inhibition was observed in sequential culture and co

348 culture.

349

350

351

352

353

354

355

356

357

358

359

360

361

362

363

364

365

366

367

368

369

370

371

372

373

374

375

376

377

378

\subsection{Cell-to-cell contact inhibition}

A co-culture of L. piscium and L. monocytogenes was performed in diffusion chambers separated by a $0.22 \mu \mathrm{m}$ membrane. In these conditions, the bacterial cells were physically separated, whereas the diffusion of nutrients and extracellular compounds through the filter was possible. Figure 5 showed that the growth of L. monocytogenes was similar to that obtained in monoculture with a maximum population of $9 \log \mathrm{CFU} \mathrm{ml}{ }^{-1}$ and a growth rate of $0.567 \mathrm{~h}^{-1}$ after $30 \mathrm{~h}$ of incubation. No bacterial inhibition was observed in this experiment till $48 \mathrm{~h}$ of incubation. These results indicate clearly that inhibition of L. monocytogenes by $L$. piscium requires cell-to-cell contact between the bacteria. Using the same approach with semi permeable membrane between cultures, Woo et al. (2011) led to the same conclusion for invitro detoxification of the pathogenic Clostridium difficile by the probiotic Clostridium butyricum MIYAIRI 588. Bavananthasivam et al. (2012), made the same observation for the inhibition of Mannheimia haemolytica by Pasteurella multocida that is also contact dependent. To our knowledge, this is the first report on a cell-contact dependent inhibition system within LAB and target bacteria.

Contact dependent inhibition mechanism can be explained by exchange of information between bacteria such as conjugation, secretion systems, contact dependent inhibition, allolysis and nanotubes. Conjugation is a horizontal transfer of genetic material between bacterial cells by direct cell-to-cell contact or by a bridge-like connection (Zechner et al., 2012). Secretion systems pathways (type IV and VI) were discovered in Gram-negative bacteria. They facilitate the transport of DNA, proteins or molecules from the bacterial cytoplasm directly into prokaryote cells (Tseng et al., 2009). The type IV secretion system is the unique type secretion system discovered in Gram-positive bacteria (Melville and Craig, 2013). In addition to these mechanisms, Aoki et al. (2005) have also demonstrated that some E. coli strains may cause contact-depending inhibition (CDI) of other E. coli strains. This system is widespread among proteobacteria (Poole et al., 2011), and was in sillico identified but not experimentally demonstrated in Gram-positive bacteria (Diner et al., 2012; Holberger et al., 2011). In 2005, Guiral et al. have observed that in nutriment starvation, the competent cells Streptococcus pneumoniae produced two cell surface bacteriocins (CibA and CibB). In contact with incompetent cells, these two bacteriocins trigger all hydrolyses and lytic proteins of incompetent bacteria, causing their autolysis. Finally, the presence of nanotubes, recently 
described by Dubey and Ben-Yehuda (2011) also allow bacteria to exchange their cellular compounds (plasmids, protein, small molecules) with neighboring cells through direct cell contact.

In conclusion, we have demonstrated that $L$. piscium CNCM I-4031 is able to inhibit the growth of L. monocytogenes in shrimp matrices and in a chemically modified medium MSMA. This inhibition is not due to the excretion of antimicrobial compounds nor to nutritional competition as frequently described for other interactions between $\mathrm{LAB}$ and $L$. monocytogenes. The exact mechanisms of inhibition were not identified, however, it was shown that cellular contact is required to obtain the inhibition of the pathogenic bacteria by $L$. piscium. This is the first report of contact dependent inhibition for LAB and further studies are in progress to elucidate the specific mechanisms that are involved in this inhibition.

\section{Acknowledgments}

Papa Abdoulaye FALL and Taous SARAOUI were the recipient of a Ph.D. fellowship from Ifremer/region Pays de Loire and the French Ministry of Higher Education and Research respectively. This study was financially supported by National French Research Agency (ANR) within the context of the ALIA (Food Research) program (project ECOBIOPRO, reference ANR-10-ALIA-018-02) 
402

403

404

405

406

407

408

409

410

411

412

413

414

415

416

417

418

419

420

421

422

423

424

425

426

427

428

429

430

431

432

433

434

Bibliography

Alomar, J., Lebert, A., Montel, M.C., 2008a. Effect of temperature and pH on growth of Staphylococcus aureus in co-culture with Lactococcus garvieae. Curr. Microbiol. 56, 408-412.

Alomar, J., Loubiere, P., Delbes, C., Nouaille, S., Montel, M.C., 2008b. Effect of Lactococcus garvieae, Lactococcus lactis and Enterococcus faecalis on the behaviour of Staphylococcus aureus in microfiltered milk. Food Microbiol. 25, 502-508.

Ananou, S., Garriga, M., Hugas, M., Maqueda, M., Martínez-Bueno, M., Gálvez, A., Valdivia, E., 2005. Control of Listeria monocytogenes in model sausages by enterocin AS-48. Int. J. Food Microbiol. 103, 179-190.

Aoki, S.K., Pamma, R., Hernday, A.D., Bickham, J.E., Braaten, B.A., Low, D.A., 2005. Contact-Dependent Inhibition of growth in Escherichia coli. Science 309, 1245-1248.

Bavananthasivam, J., Dassanayake, R.P., Kugadas, A., Shanthalingam, S., Call, D.R., Knowles, D.P., Srikumaran, S., 2012. Proximity-dependent inhibition of growth of Mannheimia haemolytica by Pasteurella multocida. Appl. Environ. Microbiol. 78, 6683-6688.

Benkerroum, N., Daoudi, A., Hamraoui, T., Ghalfi, H., Thiry, C., Duroy, M., Evrart, P., Roblain, D., Thonart, P., 2005. Lyophilized preparations of bacteriocinogenic Lactobacillus curvatus and Lactococcus lactis subsp. lactis as potential protective adjuncts to control Listeria monocytogenes in dry-fermented sausages. J. Appl. Microbiol. 98, 56-63.

Charlier, C., Cretenet, M., Even, S., Le Loir, Y., 2009. Interactions between Staphylococcus aureus and lactic acid bacteria: an old story with new perspectives. Int. J. Food Microbiol. 131, 30-39.

Delbes-Paus, C., Dorchies, G., Chaabna, Z., Callon, C., Montel, M.C., 2010. Contribution of hydrogen peroxide to the inhibition of Staphylococcus aureus by Lactococcus garvieae in interaction with raw milk microbial community. Food Microbiol. 27, 924932.

Diner, E.J., Beck, C.M., Webb, J.S., Low, D.A., Hayes, C.S., 2012. Identification of a target cell permissive factor required for contact-dependent growth inhibition (CDI). Genes Dev. 26, 515-525.

Dubey, G.P., Ben-Yehuda, S., 2011. Intercellular nanotubes mediate bacterial communication. Cell 144, 590-600. 
Dubois, M., Gilles, K.A., Hamilton, J.K., Rebers, P.A., Smith, F., 1956. Colorimetric method for determination of sugars and related substances. Anal. Chem. 28, 350-356

El-Ziney, M.G., van den Tempel, T., Debevere, J., Jakobsen, M., 1999. Application of reuterin produced by Lactobacillus reuteri 12002 for meat decontamination and preservation. J. Food Prot. 62, 257-261.

Fall, P.A., Leroi, F., Chevalier, F., Guerin, C., Pilet, M.-F., 2010a. Protective effect of a nonbacteriocinogenic Lactococcus piscium CNCM I-4031 strain against Listeria monocytogenes in sterilized tropical cooked peeled shrimp. J. Aquat. Food Prod. Technol. 19, 84-92.

Fall, P.A., Leroi, F., Cardinal, M., Chevalier, F., Pilet, M.F., 2010b. Inhibition of Brochothrix thermosphacta and sensory improvement of tropical peeled cooked shrimp by Lactococcus piscium CNCM I-4031. Lett. Appl. Microbiol. 50, 357-361.

Fall, P.A., Pilet, M.F., Leduc, F., Cardinal, M., Duflos, G., Guérin, C., Joffraud, J.J., Leroi, F., 2012. Sensory and physicochemical evolution of tropical cooked peeled shrimp inoculated by Brochothrix thermosphacta and Lactococcus piscium CNCM I-4031 during storage at $8^{\circ} \mathrm{C}$. Int. J. Food Microbiol. 152, 82-90.

Gandhi, M., Chikindas, M.L., 2007. Listeria: A foodborne pathogen that knows how to survive. Int. J. Food Microbiol. 113, 1-15.

Ghanbari, M., Jami, M., Domig, K.J., Kneifel, W., 2013. Seafood biopreservation by lactic acid bacteria - A review. Food Sci. Technol. 54, 315-324.

Guiral, S., Mitchell, T.J., Martin, B., Claverys, J.-P., 2005. Competence-programmed predation of noncompetent cells in the human pathogen Streptococcus pneumoniae: genetic requirements. Proc. Natl. Acad. Sci. U. S. A. 102, 8710-8715.

Heu, M.-S., Kim, J.-S., Shahidi, F., 2003. Components and nutritional quality of shrimp processing by-products. Food Chem. 82, 235-242.

Himelbloom, B., Nilsson, L., Gram, L., 2001. Factors affecting production of an antilisterial bacteriocin by Carnobacterium piscicola strain A9b in laboratory media and model fish systems. J. Appl. Microbiol. 91, 506-513.

Holberger, L.E., Garza-Sánchez, F., Lamoureux, J., Low, D.A., Hayes, C.S., 2011. A novel family of toxin/antitoxin proteins in Bacillus species. FEBS Lett.

Jameson, J.E., 1962. A discussion of the dynamics of salmonella enrichment. J. Hyg. (Lond.) 60, 193-207.

Jensen, P.R., Hammer, K., 1993. Minimal requirements forexponential growth of Lactococcus lactis. Appl. Environ. Microbiol. 59, 4363-4366. 
Lauret, R., Morel-Deville, F., Berthier, F., Champomier-Verges, M., Postma, P., Ehrlich, S.D., Zagorec, M., 1996. Carbohydrate utilization in Lactobacillus sake. Appl. Environ. Microbiol. 62, 1922-1927.

Lecuit, M., Leclercq, Al., 2012. Rapport d'activité de l'institut Pasteur vis-à-vis de la surveillance microbiologique de la listériose en France.

Matamoros, S., Leroi, F., Cardinal, M., Gigout, F., Kasbi Chadli, F., Cornet, J., Prévost, H., Pilet, M.F., 2009a. Psychrotrophic lactic acid bacteria used to improve the safety and quality of vacuum-packaged cooked and peeled tropical shrimp and cold-smoked salmon. J. Food Prot. 72, 365-374.

Matamoros, S., Pilet, M.-F., Gigout, F., Prevost, H., Leroi, F., 2009b. Selection and evaluation of seafood-borne psychrotrophic lactic acid bacteria as inhibitors of pathogenic and spoilage bacteria. Food Microbiol. 26, 638-644.

Melville, S., Craig, L., 2013. Type IV Pili in Gram-positive bacteria. Microbiol. Mol. Biol. Rev. 77, 323-341.

Naghmouchi K., Drider D., Fliss I. 2007. Action of divergicin M35, a class IIa bactteriocin, on liposomes and Listeria. J. Appl. Microbiol. 102, 1508-1517.

Naghmouchi K., Drider D.,Kheadr E., Lacroix C., Prevot H., Fliss I. 2006. Multiple characterizations of Listeria monocytogens sensitive and insensitive variants to divergicin M35, a new pediocin-like bacteriocin. J. Appl. Microbiol. 100, 29-39.

Nilsson, L., Hansen, T. b., Garrido, P., Buchrieser, C., Glaser, P., Knøchel, S., Gram, L., Gravesen, A., 2005. Growth inhibition of Listeria monocytogenes by a nonbacteriocinogenic Carnobacterium piscicola. J. Appl. Microbiol. 98, 172-183.

Nilsson, L., Ng, Y. y., Christiansen, J. n., Jørgensen, B. 1., Grótinum, D., Gram, L., 2004. The contribution of bacteriocin to inhibition of Listeria monocytogenes by Carnobacterium piscicola strains in cold-smoked salmon systems. J. Appl. Microbiol. 96, 133-143.

Nouaille, S., Even, S., Charlier, C., Le Loir, Y., Cocaign-Bousquet, M., Loubière, P., 2009. Transcriptomic response of Lactococcus lactis in mixed culture with Staphylococcus aureus. Appl. Environ. Microbiol. 75, 4473-4482.

Pilet, M.-F., Leroi, F., 2011. 13 - Applications of protective cultures, bacteriocins and bacteriophages in fresh seafood and seafood products, in: Lacroix, C. (Ed.), Protective cultures, antimicrobial metabolites and bacteriophages for food and beverage biopreservation, Woodhead Publishing Series in Food Science, Technology and Nutrition. Woodhead Publishing, pp. 324-347. 
Poole, S.J., Diner, E.J., Aoki, S.K., Braaten, B.A., de Roodenbeke, C.K., Low, D.A., Hayes, C.S., 2011. Identification of functional toxin/immunity genes linked to contactdependent growth inhibition (CDI) and rearrangement hotspot (Rhs) systems. PLoS Genet. 7, e1002217.

Premaratne, R.J., Lin, W.J., Johnson, E.A., 1991. Development of an improved chemically defined minimal medium for Listeria monocytogenes. Appl. Environ. Microbiol. 57, 3046-3048.

Schöbitz R., Suazo V., Costa M., Ciampi L., 2003. Effects of a bacteriocin-like inhibitory substance from Carnobacterium piscicola against human and salmon isolates of Listeria monocytogenes. Int J Food Microbiol. 84(2):237-44.

Stile M.E., 1996. Biopreservation by lactic acid bacteria. Antonie van Leeuwenhoek 70, 331345.

Richard, C., Brillet, A., Pilet, M. f., Prévost, H., Drider, D., 2003. Evidence on inhibition of Listeria monocytogenes by divercin V41 action. Lett. Appl. Microbiol. 36, 288-292.

Rihakova, J., Belguesmia, Y., Petit, V.W., Pilet, M.F., Prévost, H., Dousset, X., Drider, D., 2009. Divercin V41 from gene characterization to food applications: 1998-2008, a decade of solved and unsolved questions. Lett. Appl. Microbiol. 48, 1-7.

Tseng, T.-T., Tyler, B.M., Setubal, J.C., 2009. Protein secretion systems in bacterial-host associations, and their description in the gene ontology. BMC Microbiol. 9, S2.

Vazquez-Boland, J.A., Kuhn, M., Berche, P., Chakraborty, T., Dominguez-Bernal, G., Goebel, W., Gonzalez-Zorn, B., Wehland, J., Kreft, J., 2001. Listeria Pathogenesis and molecular virulence determinants. Clin. Microbiol. Rev. 14, 584-640.

Woo, T.D.H., Oka, K., Takahashi, M., Hojo, F., Osaki, T., Hanawa, T., Kurata, S., Yonezawa, H., Kamiya, S., 2011. Inhibition of the cytotoxic effect of Clostridium difficile in vitro by Clostridium butyricum MIYAIRI 588 strain. J. Med. Microbiol. 60, 1617-1625.

Zechner, E.L., Lang, S., Schildbach, J.F., 2012. Assembly and mechanisms of bacterial type IV secretion machines. Philos. Trans. R. Soc. B Biol. Sci. 367, 1073-1087. 
Table

\begin{tabular}{|c|c|c|c|c|c|c|c|c|}
\hline Components & Concentration $\left(\mathrm{g} \mathrm{I}^{-1}\right)$ & MSM & MSMA & MSMB & MSMC & MSMD & MSME & MSMF \\
\hline \multicolumn{9}{|l|}{ Buffer } \\
\hline $\mathrm{KH}_{2} \mathrm{PO}_{4}$ & 6,56 & $\mathrm{X}$ & $\mathrm{X}$ & $\mathrm{X}$ & $\mathrm{X}$ & $\mathrm{X}$ & $X$ & $\mathrm{X}$ \\
\hline $\mathrm{Na}_{2} \mathrm{HPO}_{4}, 7 \mathrm{H}_{2} \mathrm{O}$ & 30,96 & $\mathrm{X}$ & $\mathrm{X}$ & $\mathrm{X}$ & $\mathrm{X}$ & $\mathrm{X}$ & $\mathrm{X}$ & $\mathrm{X}$ \\
\hline \multicolumn{9}{|l|}{ Sugar } \\
\hline Glucose & 7 & $\mathrm{X}$ & $\mathrm{X}$ & $\mathrm{X}$ & $\mathrm{X}$ & $\mathrm{X}$ & $\mathrm{X}$ & $\mathrm{X}$ \\
\hline \multicolumn{9}{|l|}{ Salts } \\
\hline $\mathrm{MgSO} 4,7 \mathrm{H} 2 \mathrm{O}$ & 0,4 & $\mathrm{X}$ & $\mathrm{X}$ & $\mathrm{X}$ & $\mathrm{X}$ & $\mathrm{X}$ & $\mathrm{X}$ & $\mathrm{X}$ \\
\hline $\mathrm{NaCl}$ & 8 & $\mathrm{X}$ & $\mathrm{X}$ & $\mathrm{X}$ & $\mathrm{X}$ & $\mathrm{X}$ & $\mathrm{X}$ & $\mathrm{X}$ \\
\hline Ferric citrate & 0,088 & $\mathrm{X}$ & $\mathrm{X}$ & $\mathrm{X}$ & $\mathrm{X}$ & $\mathrm{X}$ & $\mathrm{X}$ & $\mathrm{X}$ \\
\hline \multicolumn{9}{|l|}{ Amino-acids } \\
\hline L-alanine & 0,05 & $\mathrm{X}$ & $\mathrm{X}$ & $\mathrm{X}$ & $\mathrm{X}$ & $\mathrm{X}$ & $\mathrm{X}$ & $\mathrm{X}$ \\
\hline L-arginine & 0,1 & $\mathrm{X}$ & $\mathrm{X}$ & $\mathrm{X}$ & $\mathrm{X}$ & $\mathrm{X}$ & $\mathrm{X}$ & $\mathrm{X}$ \\
\hline L-cysteine & 0,05 & $\mathrm{X}$ & $\mathrm{X}$ & $\mathrm{X}$ & $\mathrm{X}$ & $\mathrm{X}$ & $\mathrm{X}$ & $\mathrm{X}$ \\
\hline L-glutamate & 0,1 & $\mathrm{X}$ & $\mathrm{X}$ & $\mathrm{X}$ & $\mathrm{X}$ & $\mathrm{X}$ & $\mathrm{X}$ & $\mathrm{X}$ \\
\hline L-glutamine & 0,05 & $\mathrm{X}$ & $\mathrm{X}$ & $\mathrm{X}$ & $\mathrm{X}$ & $\mathrm{X}$ & $\mathrm{X}$ & $\mathrm{X}$ \\
\hline L-glycine & 0,1 & $\mathrm{X}$ & $\mathrm{X}$ & $\mathrm{X}$ & $\mathrm{X}$ & $\mathrm{X}$ & $\mathrm{X}$ & $\mathrm{X}$ \\
\hline L-histidine & 0,05 & $\mathrm{X}$ & $\mathrm{X}$ & $\mathrm{X}$ & $\mathrm{X}$ & $\mathrm{X}$ & $\mathrm{X}$ & $\mathrm{X}$ \\
\hline L-isoleucine & 0,05 & $\mathrm{X}$ & $\mathrm{X}$ & $\mathrm{X}$ & $\mathrm{X}$ & $\mathrm{X}$ & $\mathrm{X}$ & $\mathrm{X}$ \\
\hline L-leucine & 0,05 & $\mathrm{X}$ & $\mathrm{X}$ & $\mathrm{X}$ & $\mathrm{X}$ & $\mathrm{X}$ & $\mathrm{X}$ & $\mathrm{X}$ \\
\hline L-lysine & 0,1 & $\mathrm{X}$ & $\mathrm{X}$ & $\mathrm{X}$ & $\mathrm{X}$ & $\mathrm{X}$ & $\mathrm{X}$ & $\mathrm{X}$ \\
\hline L-methionine & 0,1 & $\mathrm{X}$ & $\mathrm{X}$ & $\mathrm{X}$ & $\mathrm{X}$ & $\mathrm{X}$ & $\mathrm{X}$ & $\mathrm{X}$ \\
\hline L-phenylalanine & 0,05 & $\mathrm{X}$ & $\mathrm{X}$ & $\mathrm{X}$ & $\mathrm{X}$ & $\mathrm{X}$ & $\mathrm{X}$ & $\mathrm{X}$ \\
\hline L-proline & 0,15 & $\mathrm{X}$ & $\mathrm{X}$ & $\mathrm{X}$ & $\mathrm{X}$ & $\mathrm{X}$ & $\mathrm{X}$ & $\mathrm{X}$ \\
\hline L-serine & 0,15 & $\mathrm{X}$ & $\mathrm{X}$ & $\mathrm{X}$ & $\mathrm{X}$ & $\mathrm{X}$ & $\mathrm{X}$ & $\mathrm{X}$ \\
\hline L-threonine & 0.1 & $\mathrm{X}$ & $\mathrm{X}$ & $\mathrm{X}$ & $\mathrm{X}$ & $\mathrm{X}$ & $\mathrm{X}$ & $\mathrm{X}$ \\
\hline L-valine & 0,15 & $\mathrm{X}$ & $\mathrm{X}$ & $\mathrm{X}$ & $\mathrm{X}$ & $\mathrm{X}$ & $\mathrm{X}$ & $\mathrm{X}$ \\
\hline Tryptophan & 0,1 & & $\mathrm{X}$ & & $\mathrm{X}$ & & & $\mathrm{X}$ \\
\hline Tyrosine & 0,05 & & $\mathrm{X}$ & & $\mathrm{X}$ & & & $\mathrm{X}$ \\
\hline Taurine & 0,1 & & & & & & $\mathrm{X}$ & $\mathrm{X}$ \\
\hline \multicolumn{9}{|l|}{ Vitamins } \\
\hline Riboflavin & 3. $10^{-4}$ & $\mathrm{X}$ & $\mathrm{X}$ & $\mathrm{X}$ & & & & \\
\hline Thiamine & $10^{-4}$ & $\mathrm{X}$ & $\mathrm{X}$ & $\mathrm{X}$ & & & & $\mathrm{X}$ \\
\hline Niacine & 0.015 & $\mathrm{X}$ & $\mathrm{X}$ & $\mathrm{X}$ & & & & $\mathrm{X}$ \\
\hline Vitamin B12 & 1. $10^{-5}$ & $\mathrm{X}$ & $\mathrm{X}$ & $\mathrm{X}$ & & & & $\mathrm{X}$ \\
\hline Vitamin D & 5. $10^{-6}$ & $\mathrm{X}$ & $\mathrm{X}$ & $\mathrm{X}$ & & & & \\
\hline Aminobenzoic acid & 4. $10^{-4}$ & & $\mathrm{X}$ & $\mathrm{X}$ & & & & $\mathrm{X}$ \\
\hline Folic acid & $3,2.10^{-4}$ & & $\mathrm{X}$ & $X$ & & & & $\mathrm{X}$ \\
\hline Piridoxal & 5. $10^{-4}$ & & $\mathrm{X}$ & $\mathrm{X}$ & & & & $\mathrm{X}$ \\
\hline Trace elements & & & & & & & & $\mathrm{X}$ \\
\hline $\begin{array}{l}\text { Murashigue } \\
\text { (Solution 10X) }\end{array}$ & $\mathrm{X}$ & & & & & $\mathrm{X}$ & & $X$ \\
\hline \multicolumn{9}{|l|}{ Bases } \\
\hline Adenine & 0.005 & & $\mathrm{X}$ & & & & & $\mathrm{X}$ \\
\hline Guanine & 0.01 & & $\mathrm{X}$ & & & & & $\mathrm{X}$ \\
\hline Uracil & 0.01 & & $\mathrm{X}$ & & & & & $\mathrm{X}$ \\
\hline
\end{tabular}

Table 1: Composition of the seven chemically defined Model Shrimp Medium (MSM and MSM A to F). Concentration is expressed in $\mathrm{g}^{-1}$ of medium. 


\begin{tabular}{lcc}
\hline Medium & $\begin{array}{r}\mu_{\max } \text { of L. piscium CNCM I-4031 } \\
\left(\mathrm{h}^{-1}\right)\end{array}$ & $\begin{array}{c}\mu_{\max } \text { of L. monocytogenes RF191 } \\
\left(\mathrm{h}^{-1}\right)\end{array}$ \\
\hline MSM & 0.029 & 0.018 \\
MSMA & 0.058 & 0.030 \\
MSMB & 0.043 & 0.028 \\
MSMC & 0.033 & 0.020 \\
MCMD & 0.018 & 0.014 \\
MSME & 0.043 & 0.023 \\
MSMF & 0.093 & 0.018 \\
Elliker & 0.050 & 0.037 \\
BHI & 0.066 & 0.035 \\
Shrimp juice & 0.044 & 0.033
\end{tabular}

Table 2: Maximum growth rate $\left(\mu_{\max }\right)\left(\mathrm{h}^{-1}\right)$ of Lactococcus piscium CNCM I-4031 and Listeria monocytogenes RF191 in the different developed Model shrimp Medium (MSM and MSMA to F), Elliker, BHI and shrimp juice at $8^{\circ} \mathrm{C}$. 


\begin{tabular}{lccc}
\hline Amino-acids & $\begin{array}{c}\text { Composition of } \\
\text { MSMA }\left(\mathrm{g} \mathrm{l}^{-1}\right)\end{array}$ & $\begin{array}{c}\text { Consumption of amino } \\
\text { acid by L. piscium CNCM } \\
\text { I-4031 }\left(\mathrm{g} \mathrm{l}^{-1}\right)\end{array}$ & $\begin{array}{c}\text { Consumption of amino acid } \\
\text { by L. monocytogenes RF191 } \\
\left(\mathrm{g} \mathrm{l}^{-1}\right)\end{array}$ \\
\hline Cysteine & $0.052 \pm 0.006$ & $0.049 \pm 0.005$ & $0.040 \pm 0.002$ \\
Glycine & $0.101 \pm 0.005$ & $0.032 \pm 0.006$ & $0.088 \pm 0.001$ \\
Histidine & $0,079 \pm 0,004$ & $0.042 \pm 0.002$ & $0.047 \pm 0.001$ \\
Isoleucine & $0.053 \pm 0.002$ & $0.012 \pm 0.003$ & $0.037 \pm 0.001$ \\
Leucine & $0.053 \pm 0.002$ & $0.005 \pm 0.003$ & $0.032 \pm 0.001$ \\
Lysine & $0.072 \pm 0.001$ & $0.011 \pm 0.004$ & $0.019 \pm 0.002$ \\
Methionine & $0.091 \pm 0.007$ & $0.004 \pm 0.006$ & $0.015 \pm 0.003$ \\
Phenylalanine & $0.052 \pm 0.003$ & $-0.002 \pm 0.004$ & $0.016 \pm 0.001$ \\
Proline & $0.112 \pm 0.010$ & $0.004 \pm 0.014$ & $-0.004 \pm 0.008$ \\
Serine & $0.141 \pm 0.005$ & $0.002 \pm 0.006$ & $0.010 \pm 0.005$ \\
Tryptophan & $0.026 \pm 0.002$ & $0.004 \pm 0.002$ & $0.007 \pm 0.000$ \\
Tyrosine & $0.055 \pm 0,003$ & $-0.001 \pm 0.003$ & $0.010 \pm 0.002$
\end{tabular}

Table 3: Concentration of amino acid $\left(\mathrm{g} \mathrm{l}^{-1}\right)$ in sterile MSMA and consumption after $48 \mathrm{~h}$ at $26^{\circ} \mathrm{C}$ by L. Piscium CNCM I-4031 and L. monocytogenes RF191. Glutamate, threonine, arginine and glutamine could not be measured by this method) $( \pm: 95 \%$ confidence interval) 


\section{Figures}

Figure 1: Growth of Listeria monocytogenes RF191 ( $\Delta$ ) and Lactococcus piscium CNCM I4031 ( ) in pure culture (full line) and in co-culture (dotted line) in MSMA at $26^{\circ} \mathrm{C}$.

Figure 2: Representation of Principal Component Analysis of metabolic fingerprint obtained for pure MSMA (control) and MSMA inoculated with L. piscium CNCM I-4031 or $L$. monocytogenes RF191 after $48 \mathrm{~h}$ of incubation at $26^{\circ} \mathrm{C}$.

Figure 3: Chromatograms peaks of ionized forms of uracil (A), adenine (B), guanine (C) and riboflavin (D) in pure MSMA (C) and MSMA inoculated with L. piscium CNCM I-4031 (Lp) or L. monocytogenes RF191 (Lm) after $48 \mathrm{~h}$ of incubation at $26^{\circ} \mathrm{C}$.

Figure 4: Growth of L. monocytogenes RF191 in co-culture at $26^{\circ} \mathrm{C}$ with L. piscium $\mathrm{CNCM}$ I-4031 in MSMA medium supplemented after $24 \mathrm{~h}$ with nitrogen bases, vitamins, aminoacids, iron citrate, magnesium sulfate, glucose and the mix of amino acids, vitamins and nitrogen bases.

- Indicate the time of supplementation with nutriments

- L. monocytogenes in pure culture

..... :L. monocytogenes in co-culture

.....: :L. monocytogenes in co-culture + iron citrate

... $\square$ : :L. monocytogenes in co-culture + magnesium sulfate

$. \diamond .$. :L. monocytogenes in co-culture + amino acids

$\cdots \Delta \cdots:$ L. monocytogenes in co-culture + vitamins

...... :L. monocytogenes in co-culture +nitrogen bases

-.*: :L. monocytogenes in co-culture + vitamins + amino acids + nitrogen bases

.....: :L. monocytogenes in co-culture + glucose

Figure 5: : Growth of Listeria monocytogenes RF191 ( $\mathbf{\Delta})$ and Lactococcus piscium CNCM I-4031 (-) alone (against sterile MSMA) (full line) and in co-culture (dotted line) in MSMA at $26^{\circ} \mathrm{C}$ using a diffusion chamber. 
Figure 1

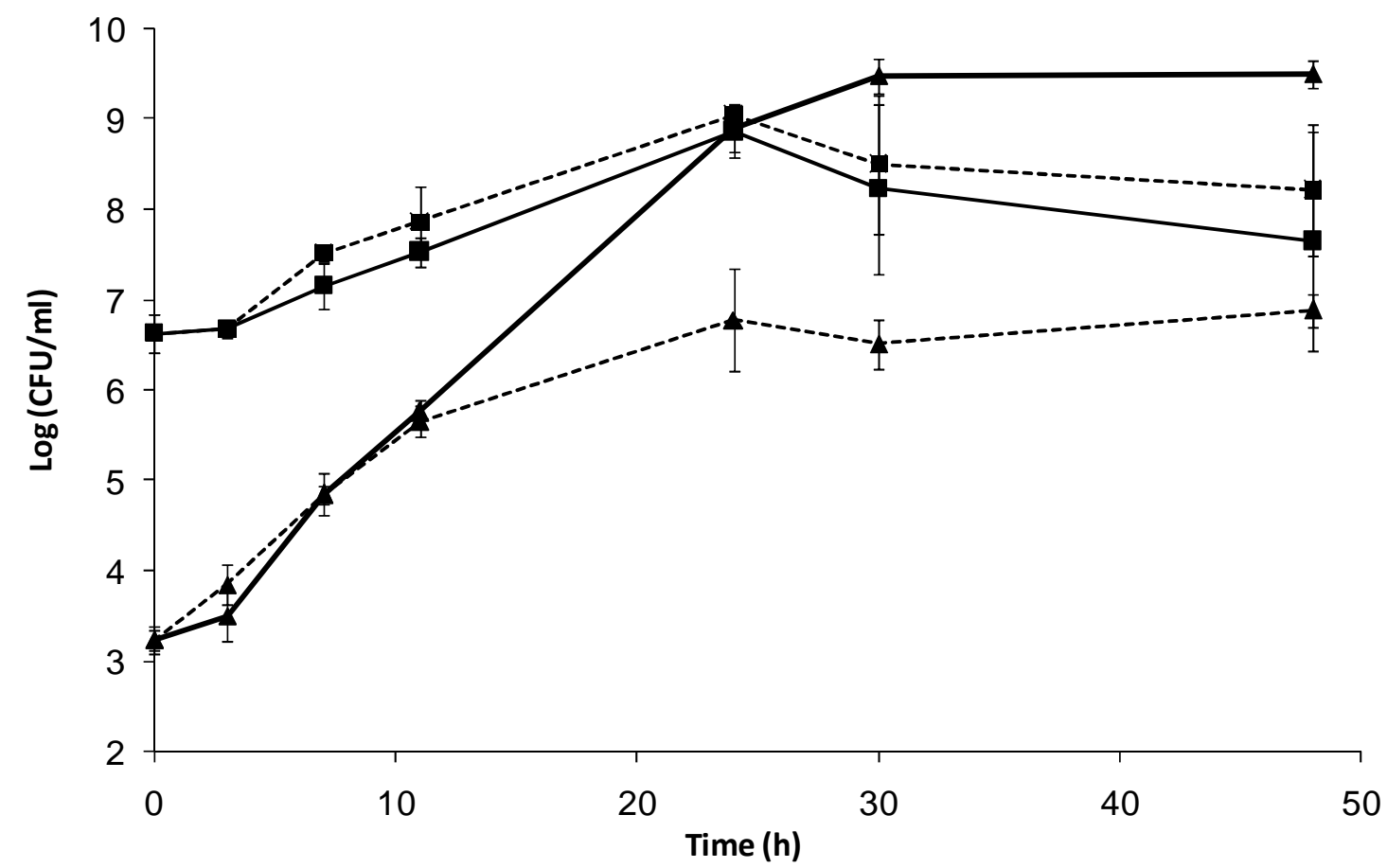

Figure 2

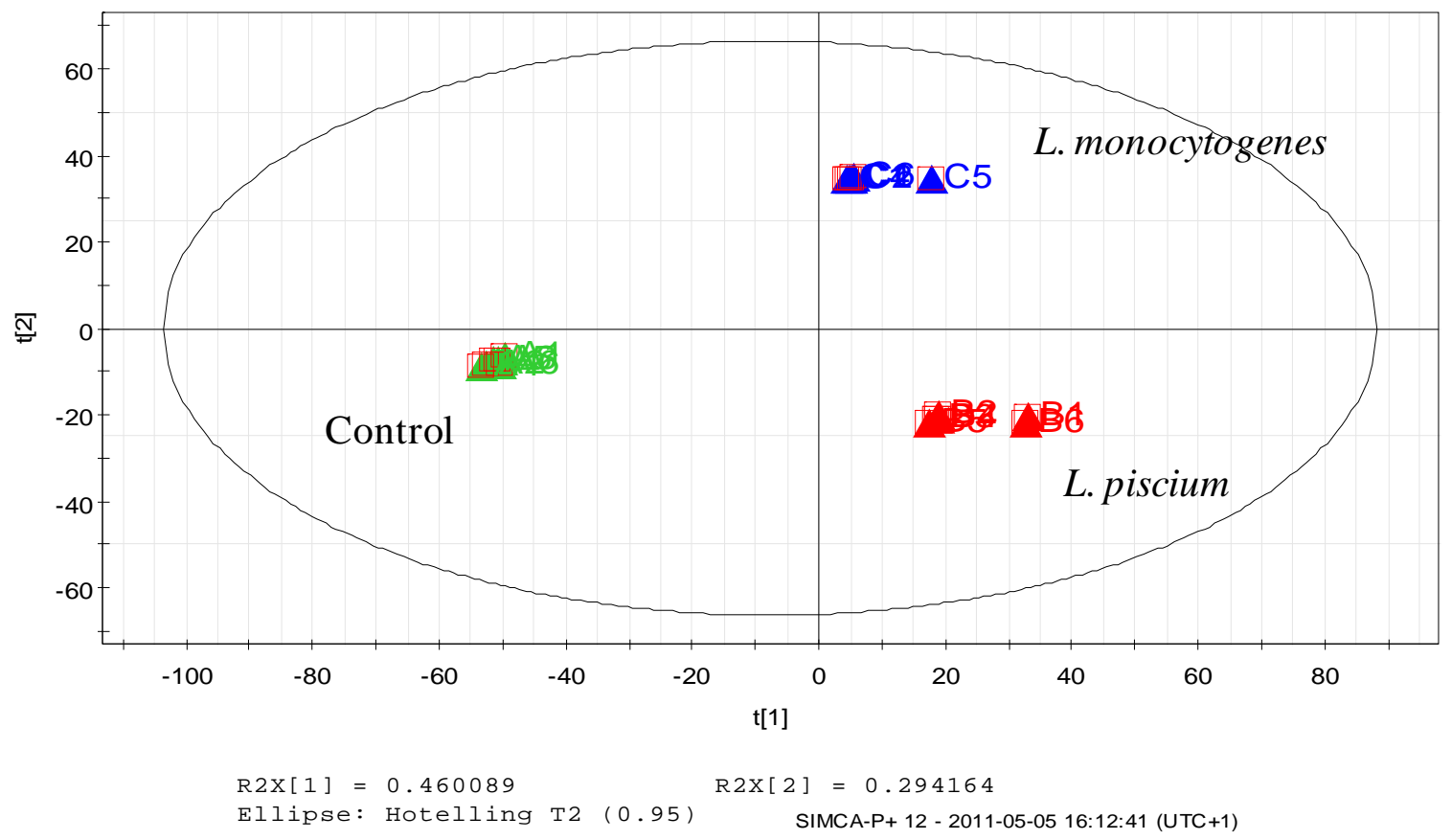


Figure 3
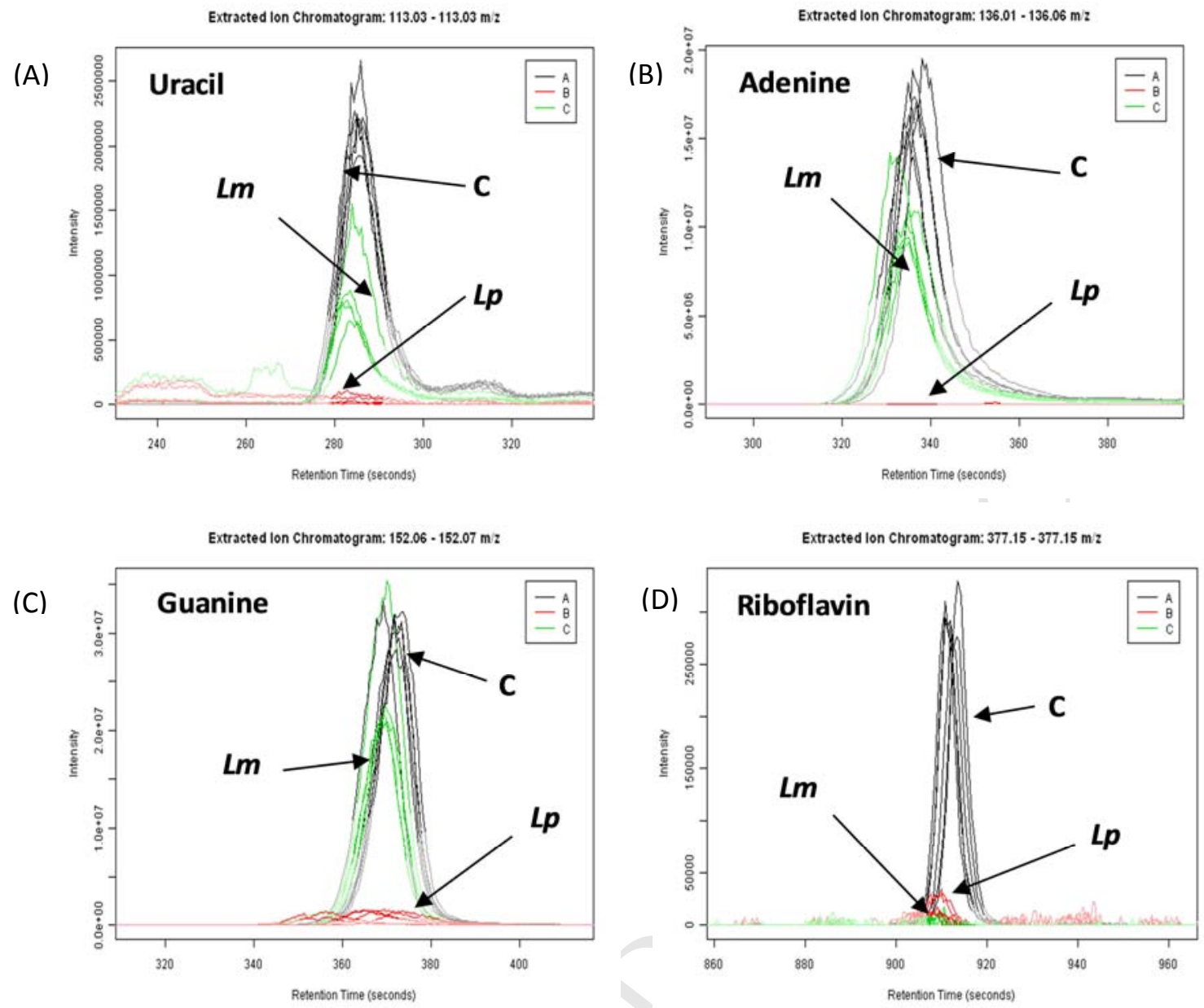
Figure 4

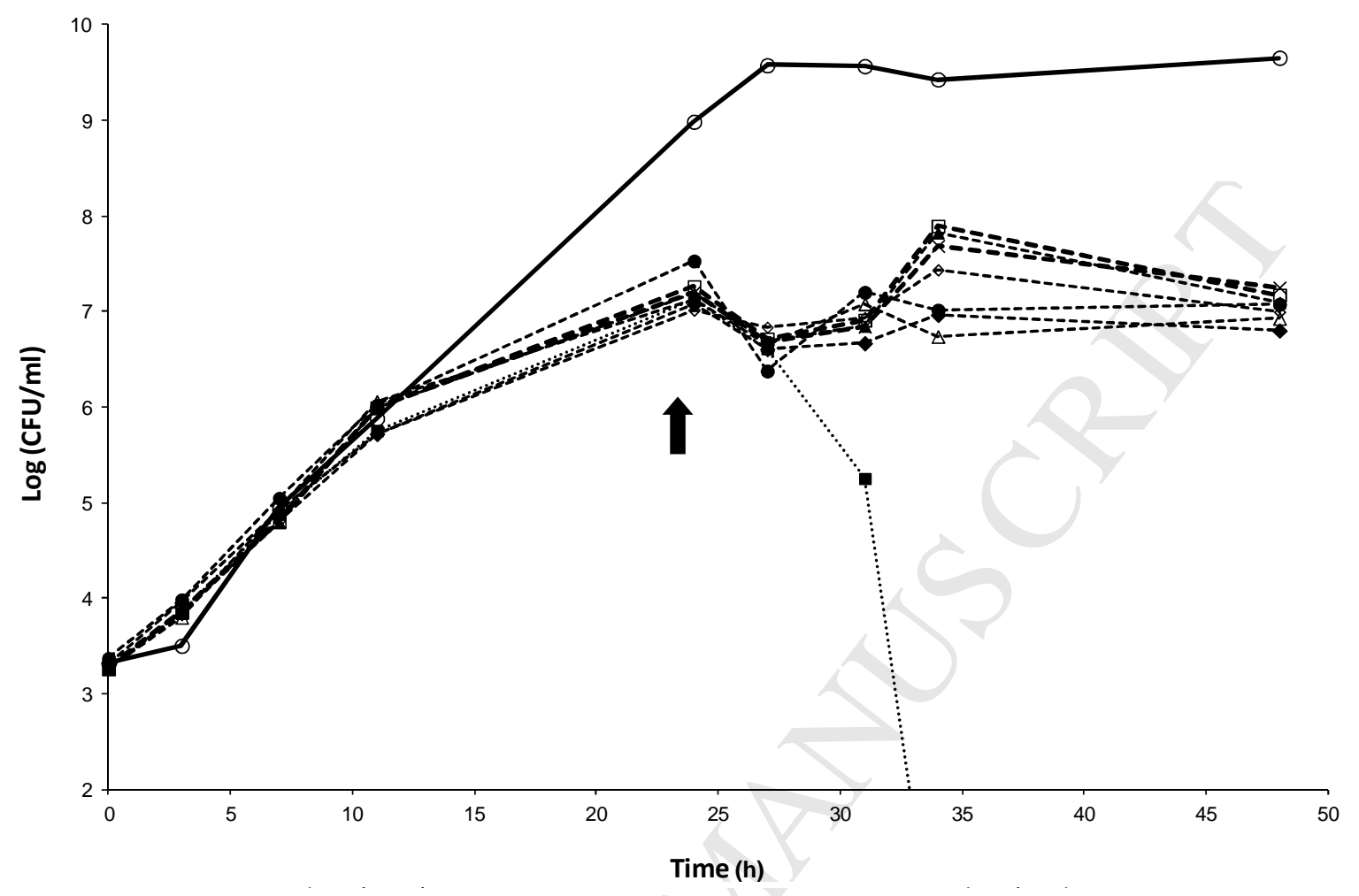

Figure 5

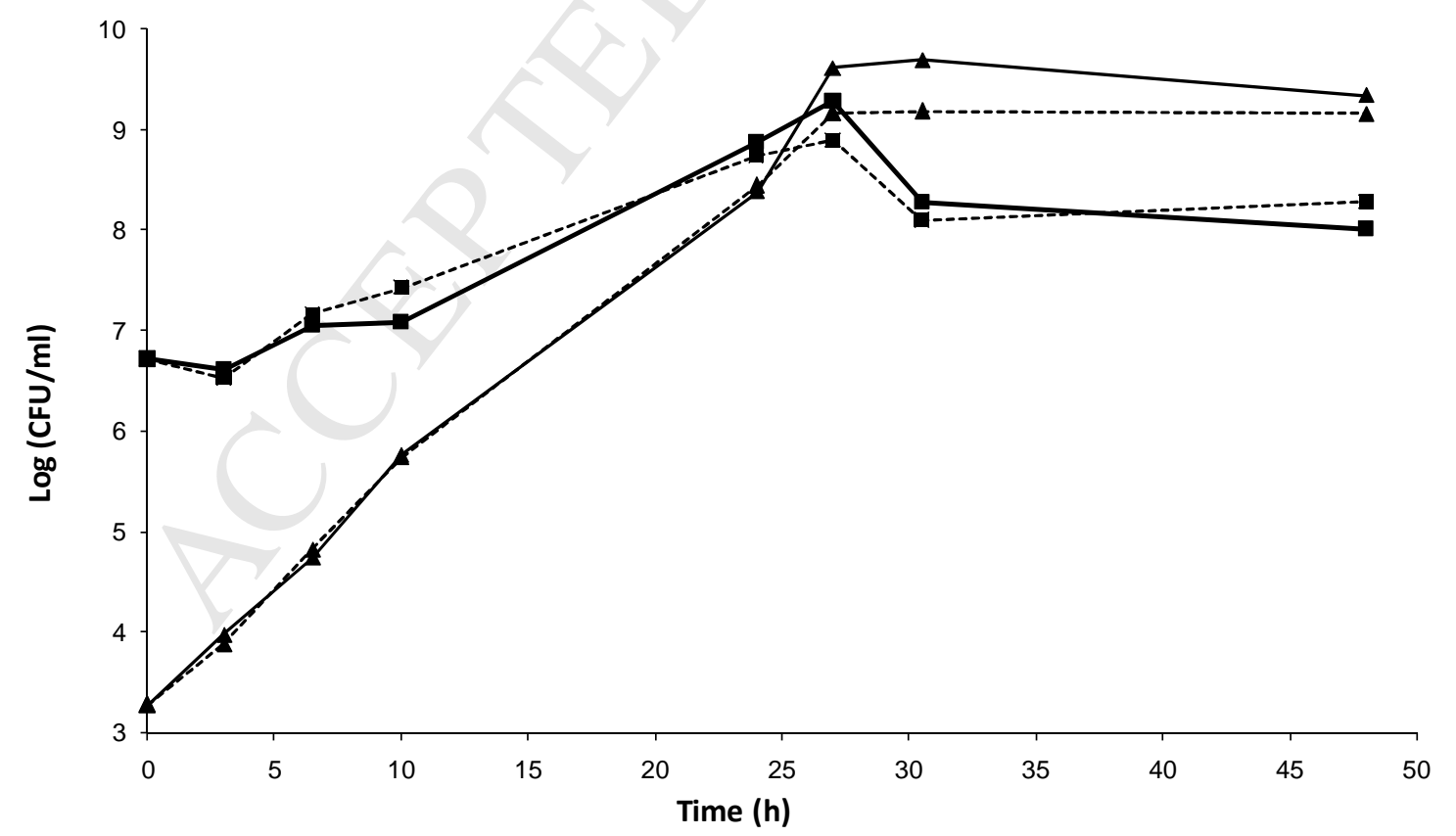

